\title{
上顎洞に達した眼窩内木片異物例
}

\author{
駒林 優樹・今田 正信・朝日 淳仁・長内 洋史 \\ 坂東 伸幸・野中聡・原㴊 保明
}

\section{Case of an Intraorbital Wooden Foreign Body Penetrating the Maxillary Sinus}

\author{
Yuki Komabayashi, Masanobu Imada, Atsuyoshi Asahi, Hiroshi Osanai, \\ Nobuyuki Bandou, Satoshi Nonaka and Yasuaki Harabuchi \\ (Asahikawa Medical College)
}

\begin{abstract}
A 62-year-old man suffered a penetrating injury to his left periorbital region with a wooden foreign body. He consulted an ophthalmologist and plastic surgeon. He was diagnosed with a conjunctival laceration and blowout fracture. His conjunctiva was consequently sutured. One month after injury, he consulted our clinic for diplopia. Severly limited trading in the upper and lower directions were observed.

Computed tomography (CT) and Magnetic resonance imaging (MRI) revealed an orbital floor fracture. When we performed an anterior orbitotomy, a $50 \mathrm{~mm}$ long, $10 \mathrm{~mm}$ wide wooden foreign body covered with granulation tissue in the orbit was found which had penetrated the maxillary sinus. It was removed from the orbit. In this case, wooden foreign body could not be identified preoperatively.
\end{abstract}

Key words : wooden foreign body, orbit, maxillary sinus

\section{はじめに}

眼窩内異物は，比較的まれであり，外傷が軽微な場合 や刺入口が非常に小さい場合,診断が困難なことが多い 今回われわれは，受傷 1力月後に診断された眼窩より上 顎洞に達した木片異物の 1 例を経験したので文献的考察 を加え報告する。

\section{症 例}

症例 : 62 歳, 男性.

主訴：複視.

既往歷：特記事項なし。

現病歴: 平成 16 年 9 月 26 日, 屋外での作業中に木片 が左顔面にぶつかり受傷した. 翌日近医を受診し，CT 上 眼窩底骨折を認めたため, 他市総合病院の形成外科, 眼 科に紹介となった。左眼球結膜裂傷の診断のもと結膜縫 合術を施行され，眼窩底骨折は保存的に経過をみられて
いた．受傷後 1カ月を経過するも左眼球の運動制限と複 視が改善しないため当院眼科を受診し，加療目的に当科 紹介となった。

初診時所見：両鼻内には異常を認めず, 煩部, 眼瞼に も腫脹や圧痛は認めなかった。

血液検查上，炎症所見は認めなかった。

眼科にて視機能検查を行い, 両眼視力はともに 1.2 (矯 正）で異常を認めなかったが，左眼に高度な上，下転障 害を認め（図 1), Hess 試験でも同様の所見を認めた。

副鼻腔 CT 所見では, 左眼窩底骨折を認め, 左上顎洞 には軟部組織陰影を認めた。 また眼窩底に一致し, 辺縁 に高吸収部分を伴う低濃度領域を認めた（図 2)。

副鼻腔 MRI 所見では，上顎洞内に T2 強調画像で高信 号領域が充満し, 左眼窩底に一致し $\mathrm{T} 1$, T2 強調画像で ともに低信号領域を認めた（図 3)。画像所見より左眼窩 底骨折とそれに伴う上顎洞内の出血と考えられた。 


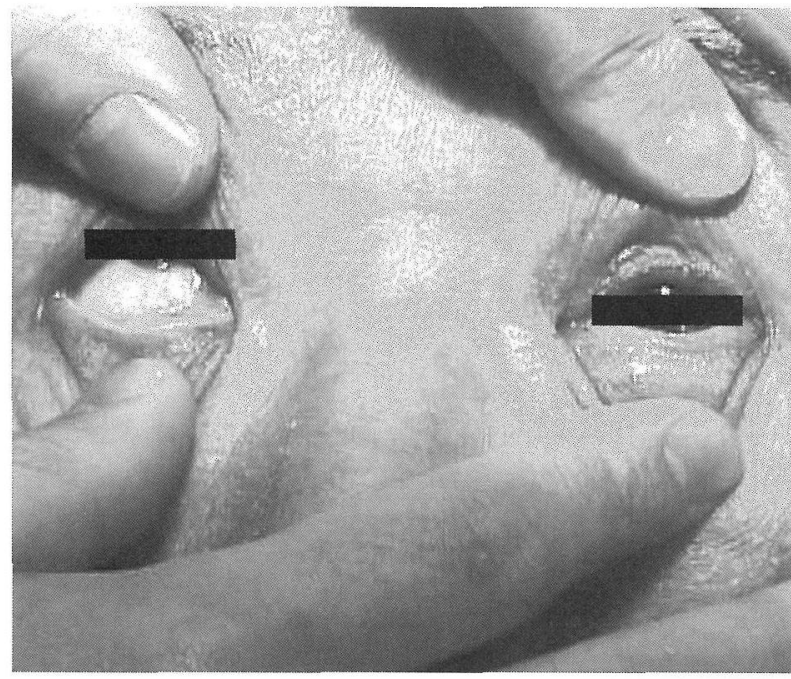

図 1 初診時所見

左眼に上転障害を認める。

左眼曧底骨折の診断で入院の上，平成 16 年 11 月 8 日 眼窩底骨折整復術を施行した。

まず犬歯窩切開を入れ上顎洞を開放し，洞内を観察し たところ，線維化した硬い痏痕組織が上壁に存在してい た。洞粘膜との癒着が強く剥離が困難であった。このた め睫毛下切開を入れ眼窩底骨膜を剥離していき，症痕組 織上縁を確認した。経眼窩的に少しずつ剥離を進めると 療痕組織内に褐色の物質を認め，一部を摘出すると木片
であることがわかった。すなわち木片は，眼窩底を破り 上顎洞に達していた。木片を周囲組織から剥離した後に 眼窩側から摘出した。摘出物は $50 \times 10 \mathrm{~mm}$ の円柱状の木 片であった（図 4)。創部を十分に洗浄し，残存異物がな いことを確認した後，眼窩底の骨欠損部にチタンプレー トを挿入し閉創した。

また，異物刺入部周囲の眼球結膜と眼瞼結膜に強い癒 着を認めたため，眼科医により両者結膜の剥離が行われ た。

術後所見：眼球運動に大きな変化は認められなかった (図 5).Hess 検査でも著変は認められなかった。

\section{考察}

眼窩内異物は，比較的まれな疾患で，眼科領域では外 来患者の $0.01 \%$ と報告されている ${ }^{1)}$ 。症状は外傷による 損傷や異物自体の物理的作用による器官損傷と異物によ る感染症状に分けられる。木片異物の場合早期に感染が 起こりやすく, 眼窩蜂窩織炎や眼窩皮膚瘦孔を形成する. また髄膜炎や脳膿瘍などの合併症を生じらる。異物が刺 入した場合，刺入部は創が非常に小さく，短時間で閉鎖 し外見上不明になる場合がある2．また，外傷自体が軽 微であり患者本人に異物刺入の自覚がない場合や眼症状 を認めないこともあり 3 ，診断が困難なことがある。特 にX線透過性の木片異物は困難で見逃されることがまれ ではない，本症例では，当科初診時には異物が刺入した

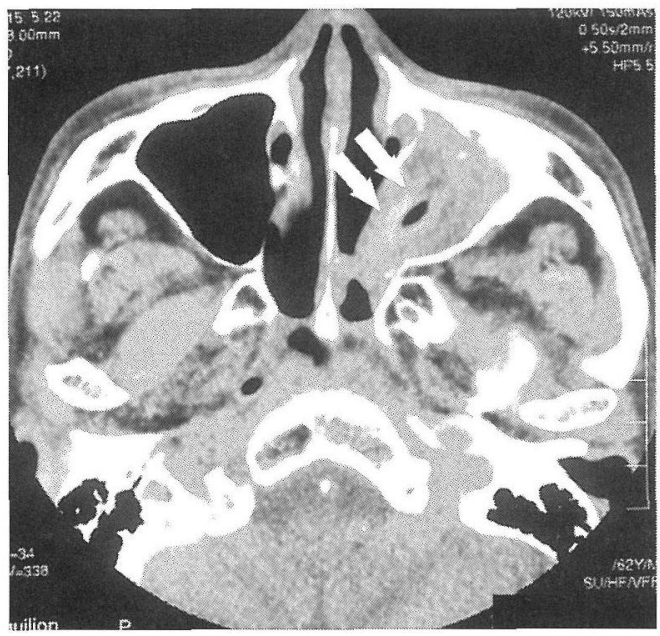

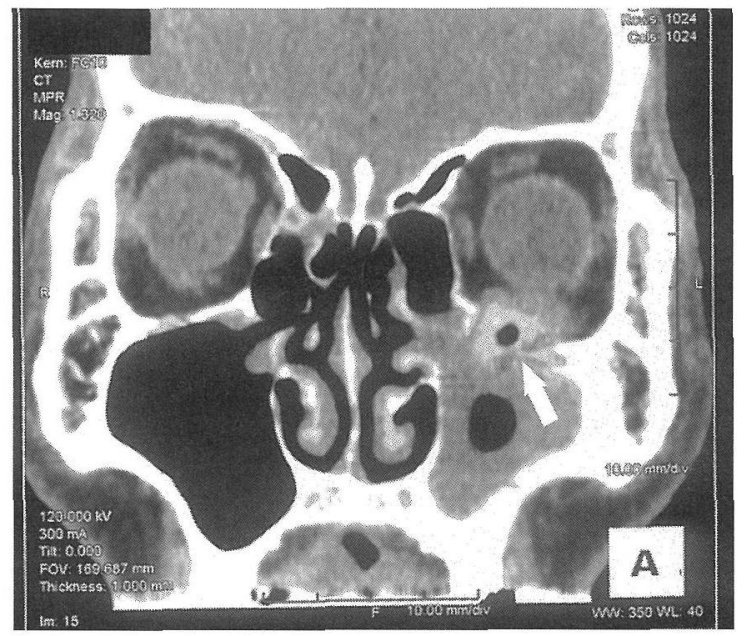

b

図 2 CT 所見（a：軸位断， b : 冠状断）

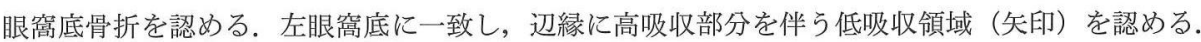




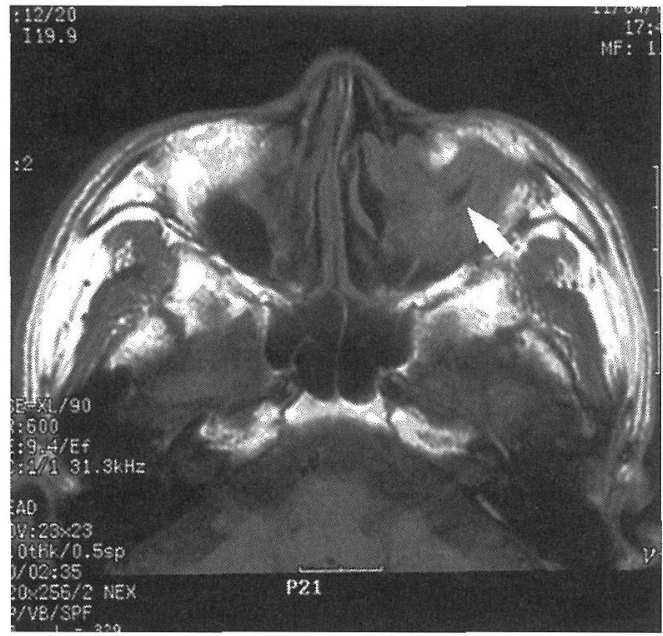

a

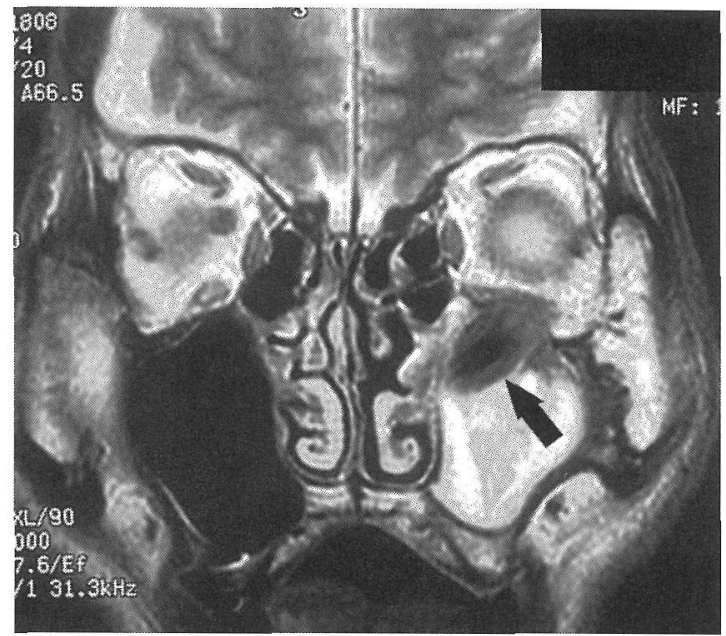

b

図 3 MRI 所見 ( $\mathrm{a} ： \mathrm{~T} 1$ 強調画像, $\mathrm{b} ： \mathrm{~T} 2$ 強調画像)

上顎洞内に T2 強調画像で高信号領域功充満. 左眼窩底に一致し T1，T2 強調画像でともに低信号領域（矢印）を認める.

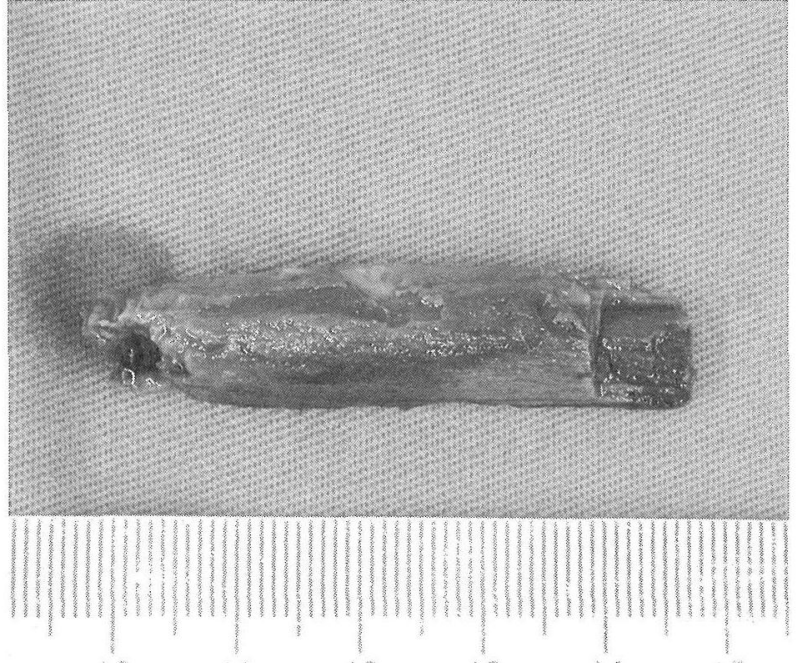

図 4 摘出物

$50 \times 10 \mathrm{~mm}$ の円柱状の木片。

と考えられる眼球結膜の創部は閉鎖されており，肉芽形 成や排膿などの感染症状を認めず，異物の存在を疑えな かった。また刺入部位について浜田 ${ }^{1)}$ は内眼角部が最も 頻度が高いと述べている。本症例では，眼球結膜であっ た.

画像検查では，CT とMRI が有効とされている。乾燥 した木片異物の場合，CT 上受傷早期には低濃度を呈す るが経過とともに水分を吸収し高濃度を示すようにな

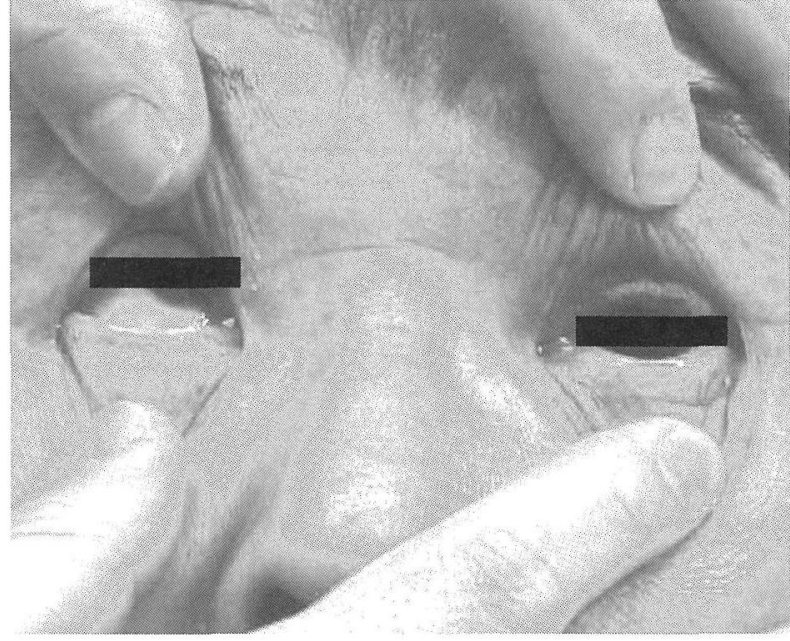

図 5 術後所見

術前と著変なく，左眼に上転障害を認める.

る45)。また MRI では，古川ら ${ }^{6)} の$ in vitro での眼窩内木 片異物モデルの検討によれば, T1 強調画像では全経過を 通じて低信号を示し，T2 強調画像では早期には低信号で あるが経過とともに高信号を示すようになると報告され ている。本症例でも後ろ向きに検討すると CT 上眼窝底 に周辺部が高濃度で中心部が低濃度を示す棒状の領域を 認め, 受傷からの期間を考慮すると報告されている特徵 と同様であった。また，MRI においても T1 強調画像で 低信号を示す異物を認めることができる。しかし，これ 
らの画像検查を用いても診断率は $50 \%$ ほどとの報告 778$)$ もあり，異物の可能性を念頭に置き，詳細な問診をとる ことが重要である.

治療については木片異物の場合, 感染による合併症を 防ぐため早期に全摘出術が行らことが重要である．本症 例においては，睫毛下および犬歯窩切開により異物を摘 出した. 術後眼球運動の改善は認められていないが，受 傷後 1 月が経過していること, 術中所見より受傷部の 瘷痕, 癒着による症状と考えられた。

\section{まとめ}

眼球結膜から刺入し眼窩底から上顎洞に達した木片異 物の 1 例を経験した。 犬歯窩, 睫毛下からのアプローチ により摘出した。 眼窩周囲の外傷では異物刺入の可能性 を意識することが重要と考えられた。

\section{参考文献}

1）浜田嶺二郎：眼窩内異物. 眼科 Mook 5 (三島済一編). 197 〜 211 頁, 金原出版, 東京, 1986 .

2) 谷内 修, 松崎 浩: 眼内異物および眼窩内異物. 眼科 25 :
$949 \sim 954,1983$.

3）村上正洋, 小川 令, 百束比呂 : 総鼻道に達した眼窩内木 片異物の 1 例. 日形会誌 $21: 353 \sim 356,2001$.

4）大谷悦子, 日山英子, 町 節子, 他: 眼窩木片異物の CT 值の経時的変化. 眼紀 $42: 1259 \sim 1262,1991$.

5）八子恵子, 鈴木美佐子, 佐々木聡, 他：眼窩内木片異物の CT 所見. 眼紀 $41: 400 \sim 406,1990$.

6）古川晶子, 田代久美子, 日山英子, 他 : 眼窩木片異物の MRI 像の経時的变化一in vitro での検討一. 眼紀 44:736〜 740, 1993.

7) Nasr AM, Barrett GH, Fleming JC, et al. : Penetrating orbital injury with organic foreign bodies. Opthalmology $106: 523 \sim$ 532, 1999.

8) Akguner M, Atabey A and Husamettin T : A case of self inflicted intraorbital injury. Ann Plast Surg 41:422 424, 1998.

原稿受付：平成17年 3 月 16 日

原稿採択：平成17年 6 月 15 日

別刷請求先：駒林優樹

テ078-8510 旭川市緑が丘東 2 条 1 丁目 1-1

旭川医科大学耳鼻咽喉科・頭頸部外科 